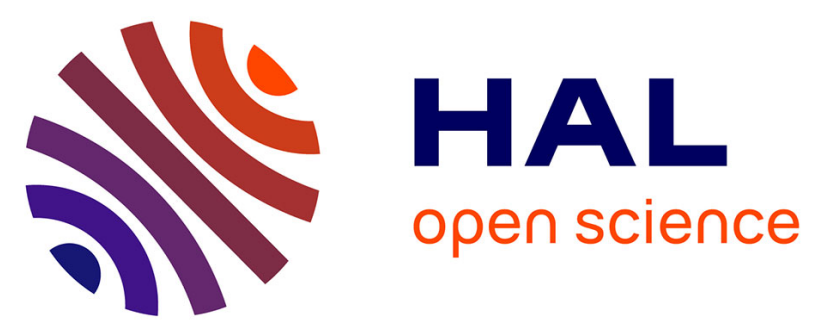

\title{
Palaeogeographical reconstructions of Lake Maliq (Korça Basin, Albania) between 14,000 BP and 2000 BP
} Eric Fouache, Michel Magny, Amandine Bordon, Stéphane Desruelles, Cécile Oberweiler, Céline Coussot, Gilles Touchais, Petrika Lera, Anne-Marie Lézine, Lionel Fadin, et al.

\section{To cite this version:}

Eric Fouache, Michel Magny, Amandine Bordon, Stéphane Desruelles, Cécile Oberweiler, et al.. Palaeogeographical reconstructions of Lake Maliq (Korça Basin, Albania) between 14,000 BP and 2000 BP. Journal of Archaeological Science, 2009, pp.525-535. 10.1016/j.jas.2009.10.017 . hal-01076711

\section{HAL Id: hal-01076711 \\ https://hal.science/hal-01076711}

Submitted on 23 Mar 2016

HAL is a multi-disciplinary open access archive for the deposit and dissemination of scientific research documents, whether they are published or not. The documents may come from teaching and research institutions in France or abroad, or from public or private research centers.
L'archive ouverte pluridisciplinaire HAL, est destinée au dépôt et à la diffusion de documents scientifiques de niveau recherche, publiés ou non, émanant des établissements d'enseignement et de recherche français ou étrangers, des laboratoires publics ou privés. 


\title{
Palaeogeographical reconstructions of Lake Maliq (Korça Basin, Albania) between
} $14000 \mathrm{BP}$ and $2000 \mathrm{BP}$

Eric Fouache ${ }^{1}$, Stéphane Desruelles ${ }^{2}$, Michel Magny ${ }^{3}$, Amandine Bordon $^{6}$, Cécile Oberweiler $^{4}$, Céline Coussot ${ }^{8}$, Gilles Touchais ${ }^{4}$, Petrika Lera ${ }^{5}$, Anne-Marie Lézine $^{6}$, Lionel Fadin ${ }^{7}$, Rébecca Roger ${ }^{9}$

${ }^{1}$ EA 375 Gecko, Université Paris Ouest Nanterre la Défense, et UMR 8591 LGP, CNRS, Meudon, France. (eric.g.fouache@orange.fr)

${ }^{2}$ JE 2532 DSA, Université de Picardie - Jules Verne, Amiens, France.

${ }^{3}$ UMR 6565 LCE, CNRS/Université de Besançon, France.

${ }^{4}$ UMR 7041 ArScAn, CNRS/Université Paris 1, France.

${ }^{5}$ Archaeological Institute, Tirana, and Archaeological Museum, Korça, Albania.

${ }^{6}$ UMR 1572 LSCE, CEA/CNRS/UVSQ, France.

${ }^{7}$ Ecole française d'Athènes, Greece.

${ }^{8}$ Institut National des Recherches Archéologiques Préventives, Direction interrégionale Centre-Ile-de-France, Pantin, France.

${ }^{9}$ Département de géographie, Université Paris 12 - Val de Marne, Créteil, France.

\begin{abstract}
Since the early 1990s, excavations of a protohistoric lakeside settlement in the Korça basin carried out by a French-Albanian archaeological team have induced geomorphological and palynological studies about the sedimentary records of Lake Maliq. These studies allow us to distinguish a series of centennial-scale high and low
\end{abstract}


lake level events between 4200-4000 cal BP (2899-2637 BC/2843-2416 BC) and 2600 cal BP (822-671 BC), probably due to large-scale climate changes (in the Mediterranean basin). In addition, the sediment sequence also gives evidence of a millennial-scale trend of lake level rise. It appears to be an interplay between lake level rises and falls against tectonic subsidence of the basin allowing accommodation space for sediment deposition.

The variations of the lake's level and the lake's surface area influenced the development and the abandonment of the nearby lakeside settlements (like the tell of Sovjan). In order to prepare an archaeological survey around the now dried up lake, we made a 3D model of the Holocene deposit from the lake including these lake level results, geomorphological mapping, excavation data, numerous core $\operatorname{logs}$, AMS ${ }^{14} \mathrm{C}$ dating and SRTM DEM data. The GIS model allowed us to propose four palaeogeographical reconstructions of the extension of Lake Maliq: around $14000 \mathrm{BP}$, during the Mesolithic (around 9000 BP - 8781-8542 BC), the Early/Middle Bronze Age transition (around 3800 BP - 2310-2042 BC) and the Iron Age (2600 BP - 822-671 BC). A map of the thickness of the sediments above potential archaeological layers is also proposed.

Keywords: SRTM DEM, GIS, geoarchaeology, geomorphology, palaeoenvironment, Holocene, Albania

\section{Introduction}

Since the early 1990s, archaeological excavations carried out in the Korça basin in Albania, and especially in Sovjan, a tell occupied from the Early Neolithic (7990 cal BP - 7060-6899 BC) until the Iron Age (2600 cal BP - 822-671 BC), have confirmed that 
people settled and developed agriculture and stock-breeding as early as the Early Neolithic (Lafe, 2005; Lera, 1990; Lera et al., 1996; Touchais et al., 2005). This is the so-called "Podgorie culture" (KOBAS, 2005; Korkuti, 1995; Prendi, 1990). The Northern area of the basin was occupied by Lake Maliq until drainage works at the end of 1950s. The lake's surface area varied between a minimum of $40 \mathrm{~km}^{2}$ during periods of low level to a maximum of $80 \mathrm{~km}^{2}$ during high stands (Fouache et al., 2001). From the Early Neolithic to the Early Iron Age, and especially during the Early/Middle Bronze Age transition (around $3800 \mathrm{cal}$ BP - 2310-2042 BC), the nearby lake shore was occupied by numerous settlements (Fig. 1) such as Maliq, the only "palaffitic" site studied in the basin (Prendi, 1966) and Sovjan, a lakeside site (Touchais et al., 2005).

In order to ascertain more detailed information on other settlements and to establish a model of human settlements around Lake Maliq, the French-Albanian archaeological team undertook land surveys around the lake. As part of these surveys, we undertook reconstructions of Lake Maliq for specific periods; namely for $14000 \mathrm{cal} \mathrm{BP}$, the Mesolithic (around 9000 cal BP - 8781-8542 BC), the Early/Middle Bronze Age transition (around $3800 \mathrm{cal}$ BP - 2310-2042 BC) and the Iron Age (2600 cal BP - 822$671 \mathrm{BC})$. These reconstructions were established using GIS and DEM including geological and new palaeoenvironnemental and archaeological data. In addition, these reconstructions allow us to discuss the influence of Holocene climatic variability on fluctuations in the palaeo-levels of Lake Maliq.

\section{Regional setting}

\subsection{Geology and geomorphology}


Lake Maliq lies in the north-western part of the Korça basin, a graben valley, asymmetric in shape with a much higher scarp to the east (Fig. 2), located at $818 \mathrm{~m}$ a.s.l. and surrounded by highlands which reach $2028 \mathrm{~m}$ (Mali Thatë - Fig. 1). Limestone and ophiolite occupy the east of the basin, while molasses only outcrop to the west. While the nearby lakes of Prespa and Ohrid are permanent lakes with a karst regime (a landscape on limestone rock through which groundwater percolates, with submerged poljes), the Korça basin, outside the karst area, is drained by the river Devoll.

Tectonic activity during the Quaternary (Tagari et al., 1993) isolated the Korça graben within its present geological borders. However, the neotectonic subsidence did not exceed 0.15 to $0.20 \mathrm{~mm} \mathrm{y}^{-1}$ (Dufaure et al., 1999) in the centre of the plain and cannot alone account for the substantial variations in the lake level.

\subsection{Climate and vegetation}

The local climate is characterized by annual rainfall averaging $800-1000 \mathrm{~mm}$ with maxima in winter $(75-100 \mathrm{~mm})$, and temperatures varying from $23^{\circ} \mathrm{C}$ to $25^{\circ} \mathrm{C}$ in July to $2^{\circ} \mathrm{C}$ to $5^{\circ} \mathrm{C}$ in January. The present-day vegetation is of the sub-Mediterranean type with an altitudinal distribution of the plant communities. The lower mountain slopes, up to about 1200 m a.s.1., are dominated by mixed deciduous forests with Carpinus orientalis, Acer monspessulanum, Pistacia terebinthus, Fraxinus ornus and Phillyrea latifolia. The upper slopes are covered by oak forests where Quercus trojana, $Q$. frainetto, Q. cerris may be locally associated with Pinus leucodermis, Juniperus excelsa, J. foetidissima and Aesculus hippocastanum. Beech woods, with Fagus moesiaca, Abies alba and Abies borisii-regis, are found above the oak forests, up to 
$1800 \mathrm{~m}$ a.s.l. Then, above approximately $1800 \mathrm{~m}$ a.s.l., sub-alpine moors and grasslands are present.

\subsection{Holocene climatic variability}

Quantitative estimates from pollen data (Denèfle et al., 2000) of monthly temperature and precipitation changes (Bordon et al., 2009) suggest that, during the Oldest Dryas, from 16000 cal BP to 15100 cal BP, expansion of cold steppe dominated by Artemisia and Poaceae was related to low temperatures in both summer and winter, and annual precipitation totals lower than approximately $400 \mathrm{~mm}$. Rainfall was $30 \mathrm{~mm}$ higher than today in average in summer and $60 \mathrm{~mm}$ lower in winter.

From 15100 cal BP to 12800 cal BP, during the Bølling/Allerød, steppes were progressively replaced by temperate deciduous forests in relation to temperate climate conditions close to modern values.

From 12800 cal BP to 11300 cal BP (Younger Dryas), a return of cold and dry conditions led to the wide expansion of steppes.

Then, during the first part of the Holocene, from 11300 cal BP onward, remarkably stable environmental conditions prevailed in the Korça basin with vegetation dominated by elements characteristic of temperate deciduous forests, and climate conditions similar to the present day.

A short-lived arid event punctuated this overall temperate period at $8200 \mathrm{cal} \mathrm{BP}$ (7445-7064 BC). The climate was characterized by a decrease in annual rainfall of 250 mm compared to the mean Holocene value and low temperatures responsible for the degradation of the forest at Maliq. 
From 1000 cal BP to the present, the climate reconstructions show large variability and major oscillations both in temperature and precipitation.

Climate conditions during the Holocene at Maliq were not as cool and moist than those recorded elsewhere in the Mediterranean area (Cheddadi et al., 1997; Huntley and Prentice, 1988; Masson et al., 1999; Roberts et al., 2001; Sadori and Narcisi, 2001), probably in relation with the steep altitudinal gradient in the basin. The reconstructed temperatures record high amplitude changes, between $-5^{\circ} \mathrm{C}$ and $10^{\circ} \mathrm{C}$ from $8200 \mathrm{cal} \mathrm{BP}$ (7445-7064 BC) to $1000 \mathrm{cal}$ BP (ca 1000 AD) (Fig. 3), probably enhanced by the topography of the Korça basin. There is a clear difference in the annual distribution of rainfall between warm and cold phases with a maximum in summer during the cold phases (Older and Younger Dryas, $8200 \mathrm{BP}$ event) and a minimum during the temperate phases (Bølling, Allerød, Holocene). The seasonality of precipitation thus appears to be a crucial climatic parameter to consider in the Mediterranean palaeo-climate reconstructions, as observed in other place in the Near-East (Bar Matthews et al., 1998; Bar Matthews et al., 2003; Bar Matthews and Ayalon, 2004; Bookman et al., 2004; Enzel et al., 2003; Frumkin, 1997; Stevens et al., 2006).

\section{Methods}

Here we use catchment geomorphological mapping techniques, lithostratigraphy description and palynological analyses from cores taken along a $150 \mathrm{~m}$ long transect (from the archaeological site of Sovjan to the centre of the palaeo-lake) to characterize the sedimentary deposits in the Korça basin to reconstruct palaeoenvironmental changes. The aim of this study is to complement the archaeological excavations of the Korça Basin and to derive greater knowledge and understanding of human-environment 
interactions in this part of Albania. This requires a combined approach of natural and cultural dynamics through time (Touchais and Fouache, 2007). Attention is paid here to fluctuations of the lake level in the Korça basin and their impact on human settlements, in particular on the tell of Sovjan, continuously excavated and studied since the 1990s. In order to achieve this, we have embedded archaeological, geological, topographic and DEM data into a GIS model.

\subsection{DEM creation using SRTM data}

Topographic data used for the study of the Korça Basin come from NASA SRTM3 data (Shuttle Radar Topography Mission - Fig. 4). In spite of the $30 \mathrm{~m}$ spatial resolution (Farr et al., 2007), these data were preferred as opposed to topographic information provided by the Albanian maps: in our study area, the most precise topographic maps (1:25 000 scale), published in 1982, have $5 \mathrm{~m}$ interval contour lines in plain. Because this interval thus does not allow us to discriminate the topography of the centre of the Lake Maliq basin, SRTM data were used. The quality of SRTM data was controlled with differential GPS (DGPS) measurements on two transects (E/W and N/S) along the plain of the Korça Basin. These two types of topographic data are based on the WGS84 projection system associated with the EGM96 geoïd. On average, the heights of the cartography resulting from SRTM data are $1.80 \mathrm{~m}$ higher than the altitudes provided by the DGPS. This difference appears to be in conformity with that usually observed in flat regions ( $<2 \mathrm{~m}-$ Rodriguez et al., 2005). SRTM data were added in the GIS of the Korça Basin, created with the ESRI ArcGIS 9.1 software. DEM and contour lines were created with the 3DAnalyst extension. 


\subsection{Geological and palaeoenvironmental data integration into the GIS to reconstruct}

the palaeo-topography of the Korça basin

Unpublished data (Fig. 5) from the geological service in Korça (101 logs obtained in 1974 by core-drilling, E/W and N/S profiles) allowed us to reconstruct the subsurface geometry of Lake Maliq, and in particular the bottom of the basin before its infilling by peat. This reconstruction was necessary, because the elevation of the low lake levels is lower than the current minimal height of the Korça basin. Heights of the palaeotopography of the plain of the Korça Basin, interpreted using the core log, were integrated into the GIS.

\subsection{Palaeoenvironmental analyses on cores to establish chronostratigraphy of the} palaeo-lake Maliq

Past water level fluctuations of Lake Maliq were reconstructed using changes in the lithology (Digerfeldt, 1986; Magny, 2006) observed along the $150 \mathrm{~m}$ long core transect (Fig. 6). Organic deposits (peat, anmoor) characterize overgrowing processes and littoral mires. Grey-blue to green-blue silt and silty-clay deposits include freshwater mollusc tests and correspond to sedimentation in open deeper water. The upper brown silt layer which overlay the peat deposits in cores K4 to K10 (above level ca $815 \mathrm{~m}$ a.s.l.) corresponds to lake deposits mixed with substantial detritic inputs (erosion due to an intense period of human impact in the catchment area during the last two millennia). The pollinic studies carried out in the Korça Basin (Denèfle et al., 2000; Fouache et al., 2001) show a continuous and high anthropogenic impact on the vegetation from 4500 cal BP (3300-3000 BC), with phases of higher impact towards 3000-2500 cal BP (1400- 
$1000 \mathrm{BC} / 800-450 \mathrm{BC})$ and towards $1500 \mathrm{BP}$ (450-650 AD, corresponding to Late Antiquity and the beginning of the Middle Age).

The core transect provides a comprehensive stratigraphic section of the littoral sediment sequence, so that the geometry of the layers and the lateral variability of the lithological facies can be highlighted.

The ages of the lake level changes identified from the sediment sequence have been inferred from radiocarbon and archaeological dating (Fouache et al., 2001; Touchais and Fouache, 2007). Six ${ }^{14} \mathrm{C}$ measurements have been retained (table 1) and converted into calendar ages (cal BP) using calibration from Reimer et al. (2004). Thus, the estimation of the lake level fluctuations and the past positions of the water table were based on two lines of evidence as follows:

- Firstly, the lithology and the composition of sediment as illustrated in figure 6 . It is assumed that (1) the depth data of the organic layers (peat) was in equilibrium with or ca $0.50 \mathrm{~m}$ above the mean water table, and (2) silt and silty-clay layers corresponded to at least $0.50 \mathrm{~m}-1 \mathrm{~m}$ water depth.

- Secondly, the altitude above sea level where the respective layers of deposits have been observed in the sediment sequence (Fig. 6).

\section{Results}

The sediment sequence of Lake Maliq allows us to distinguish a series of centennialscale high and low lake level events which punctuated the Holocene period (Fig. 10). In particular, the radiocarbon ages obtained in core $\mathrm{K} 5$ and $\mathrm{K} 1$ indicate that the first formation of peat in the southwestern shore area of Lake Maliq occurred between $9400 \mathrm{cal} \mathrm{BP}(8781-8542 \mathrm{BC})$ and $8100 \mathrm{cal} \mathrm{BP}(7090-7046 \mathrm{BC})$. 
This peat deposition may reflect an overgrowing process or a lake level lowering, or it may have resulted from a combination of both processes. During this phase, corresponding to the end of the Mesolithic and the beginning of the Neolithic, the lake level was at ca $810-811.50 \mathrm{~m}$ a.s.1.

The upper part of the peat deposits, which accumulated before the formation of layer $\mathrm{H}$, includes many wood fragments which indicates that the lake level was at ca 812$812.50 \mathrm{~m}$ a.s.l. between ca $6000 \mathrm{cal}$ BP (5062-4830 BC) and $3800 \mathrm{cal} \mathrm{BP} \mathrm{(2310-2042}$ $\mathrm{BC})$.

The deposition of the silty-clay layer $\mathrm{H}$ observed in cores $\mathrm{K} 1, \mathrm{~K} 2, \mathrm{~K} 3$ and $\mathrm{K} 5$ coincides with a highstand of the water table which may have reached 814.50-815 m a.s.l. between ca $4200 \mathrm{cal} \mathrm{BP}$ (2899-2637 BC) and $4000 \mathrm{cal} \mathrm{BP}(2843-2416$ BC).

This layer (observed in cores K1, K2 and K3) was contemporaneous with the development of the tell from the late Early Bronze Age to the Iron Age (ca 4000 cal BP2600 cal BP (2843-2416 BC/822-671 BC). It was also synchronous with an accumulation of peat in cores $\mathrm{K} 4$ and $\mathrm{K} 5$. The water table probably stood below $814 \mathrm{~m}$ a.s.1.

The abandonment of the tell during the Iron Age (at around 2600 cal BP - 822-671 BC) was followed by the deposition of a clay layer which overlaid the highest parts of the tell of Sovjan and marks a high lake level. The water table may have reached 816.50-817 m a.s.1.

During the Roman period, the lake level returned to a lower stand (less than 814$814.50 \mathrm{~m}$ a.s.1.) as indicated by the deposition of peat which commenced at ca $2000 \mathrm{cal}$ BP (51 BC-72 AD). 
This low stand was followed by higher lake level conditions that resulted in the deposition of a $1 \mathrm{~m}$-thick layer of lacustrine silt and erosive inputs (water table above 815.50-816 $\mathrm{m}$ a.s.l).

These lake level results were subsequently integrated into the GIS model which allowed us to propose four palaeogeographical reconstructions of the extension of Lake Maliq (Fig. 7) at stages when its level was high.

\section{Discussion}

The present day mean subsidence rate of the Lake Maliq basin is estimated between 0.15 and $0.20 \mathrm{~mm} \mathrm{y}^{-1}$ (Dufaure et al., 1999). Before the drainage works and especially prior the water abstraction, it was noticeably lower but the subsidence rate accounts for the thickness of the Holocene sediment.

The accumulation of peaty deposits, the thickness of which exceeds $4.50 \mathrm{~m}$, suggests that the water table of Lake Maliq (latitude: $40^{\circ} 45^{\prime} \mathrm{N}$; altitude: $818 \mathrm{~m}$ a.s.l.) was characterized by a progressive rise since the mid-Holocene. The rising millennial-scale trend contrasts with that reconstructed for the same period at Lake Xinias (latitude: $39^{\circ} 45^{\prime} \mathrm{N}$; altitude: $500 \mathrm{~m}$ a.s.l. - Digerfeldt et al., 2007), but it is in agreement with that established at Lake Accesa in Tuscany (latitude: $43^{\circ} \mathrm{N}$; altitude: $157 \mathrm{~m}$ a.s.1.- Magny $e t$ $a l ., 2007)$. It may be a reflection of a possible NW-SE contrast in climate history during the Holocene in the Mediterranean area as suggested by Roberts et al. (2008). Nevertheless, it is also possible that, during the second half of the Holocene, anthropogenic forest clearances may have induced increasing erosion in the catchment area and, more particularly, may have been responsible for an accumulation of colluvial deposits in the outlet area (Denèfle et al., 2000; Fouache et al., 2001). 
Such a subsidence rate (estimated between 0.15 and $0.20 \mathrm{~mm} \mathrm{y}^{-1}$ ) can thus only partially explain such an important accumulation of peat. In addition, it is clearly too small to explain the relatively quick changes in lake level as observed at ca $4200 \mathrm{cal}$ BP (2899-2637 BC) and between the Iron Age and Roman period (ca 2600 cal BP - 2000 cal BP, corresponding to 822-671 BC/51 BC-72 AD).

These relatively abrupt changes are most probably attributable to climatic fluctuations (seasonal change in precipitation or temperature). Two of the distinct centennial-scale high lake level events can be related to large-scale climate changes (Bordon et al., 2009; Di Rita and Magri, 2009; Drysdale et al., 2006; Magny et al., 2009; Marchant and Hooghiemstra, 2004; van Geel et al., 1996):

- the first, between 4200-4000 cal BP (2899-2637 BC/2843-2416 BC) may have been a local expression of climate change dated to $4200 \mathrm{cal} \mathrm{BP}$,

- the second, around 2600 cal BP (822-671 BC) may be due to climate change dated to 2700 cal BP (896-795 BC).

Thus, lake level data provided by this study appear to be an interplay between lake level rises and falls against tectonic subsidence of the basin allowing accommodation space for sediment deposition.

Our results do not permit us to conclude that the rise in the lake level was responsible for the abandonment of the site of Sovjan during the Iron Age. However, we may suggest that it did play a part in it. The higher lake levels, together with the knowledge of the thickness of the sediment, have allowed us to design a predictive map of the potential archaeological layers for the Neolithic and the Bronze Age (Fig. 8 and 9). The preliminary results of the survey carried out in August 2008 show a reliable correlation between the location of the sites dating back to these periods and our reconstructions 
over the periods in question. However, they also show that the medieval sites dating back to the $8^{\text {th }}$ and $9^{\text {th }}$ centuries $\mathrm{AD}$ are all located slightly inward with regard to the lowest lake level we reconstructed. This shows that a very low lake level did exist at that time and that our palaeoenvironmental reconstructions need to be extended over the past 2000 years.

\section{Conclusion}

The regional study carried out around Lake Maliq demonstrates that, in order to assess correctly the surface archaeological potential as well as that of the Holocene sedimentary layers, it is necessary to take into account the variability of lake levels and of the associated sediments.

The integration of the geological and geomorphological data from these Holocene layers into a GIS and a DEM permits 3D modelling of the basin, a regular update of this model that easily integrates the new data, and provides synthetic maps of use to archaeologists and developers alike. In the long run, these maps also enable precise palaeogeographical reconstructions to be carried out.

Our research will continue towards relating higher lake levels to precise climatic events, towards comparing lakes Prespa and Ohrid on a regional scale but also making a palaeogeographical atlas of the areas around the lake from the Early Neolithic to the present day.

\section{Acknowledgements}

Many thanks are addressed to the French CNRS through the ECLIPSE project coordinated by A.-M. Lézine and E. Fouache, entitled "Variations climatiques et 
dynamique des écosystèmes au Sud des Balkans au cours du dernier cycle climatique”. The study was supported by the French-Albanian archaeological cooperative project, the French Archaeological School at Athens (Greece), the Archaeological Museum of Korça (Albania) and ARTEMIS AMS facilities in Saclay (France).

The authors warmly thank Dr. Cecile Fouache-Loire for the English improvement and the anonymous reviewer for its comments and suggestions.

\section{References}

Bar Matthews, M., Ayalon, A., Kaufman, A.,1998. Middle to Late Holocene (6,500 Yr. Period) Paleoclimate in the Eastern Mediterranean region from stable isotopic composition of Speleothems from Soreq Cave, Israel in: Issar, A.S., Brown, N. (Eds.), Water, Environment and Society in Times of Climatic Change. Kluwer Academic Publishers, pp. 203-214.

Bar-Matthews, M., Ayalon, A., Gilmour, M., Matthews, M., Hawkesworth, C., 2003. Sea-land isotopic relationships from planktonic foraminifera and speleothems in the Eastern Mediterranean region and their implications for paleorainfall during interglacial intervals. Geochimica et Cosmochimica Acta. 67, 3181-3199.

Bar-Matthews, M., Ayalon, A., 2004. Speleothems as paleoclimate indicators, a case study from Soreq cave located in the Eastern Mediterranean region, Israel in: Battarbee, R.W., Gasse, F., Tickley, C.E. (Eds.), Past Climate Variability through Europe and Africa. Kluwer Academic Publishers, pp. 363-391.

Bookman, R., Enzel, Y., Agnon, A., Stein, M., 2004. Late Holocene lake-levels of the Dead Sea. Bulletin of the Geological Society of America. 116, 555-571. 
Bordon, A., Peyron, O., Lézine, A.-M., Brewer, S., Fouache, E., 2009. Pollen-inferred Late-Glacial and Holocene climate in southern Balkans (Lake Maliq). Quaternary International. 200, 1-2, 19-30.

Cheddadi, R., Yu, G., Guiot, J., Harrison, S.P., Prentice, I.C., 1997. The climate of Europe 6000 years ago. Climate Dynamics. 13, 1-9.

Denèfle, M., Lézine, A.-M., Fouache, E., Dufaure, J.-J., 2000. A 12000-Year Pollen Record from Lake Maliq, Albania. Quaternary Research. 54, 423-432.

Digerfeldt, G., 1986. Studies on past lake-level fluctuations in: Berglund, B.E. (Ed.), Handbook of Holocene Palaeoecology and Palaeohydrology. Wiley \& Sons, Chichester, pp. 127-143.

Digerfeldt, G., Sandgren, P., Olsson, S., 2007. Reconstruction of Holocene lake-level changes in Lake Xinias, central Greece. The Holocene. 17, 361-367.

Di Rita, F., Magri, D., 2009. Holocene drought, deforestation and evergreen vegetation development in the Central Mediterranean: a 5500 year record from Lago Alimini Piccolo, Apulia, southeast Italy. The Holocene, 19, 295-306.

Drysdale, R., Zanchetta, G., Hellstrom, J., Maas, R., Fallick, A., Pickett, M., Cartwright, I., Piccini, L., 2006. Late Holocene drought responsible for the collapse of Old World civilizations is recorded in an Italian cave flowstone. Geology. 34, 101-104.

Dufaure, J.-J., Fouache, E., Denèfle, M., 1999. Tectonics and geomorphological evolution: the example of the Korça basin (Albania). Géomorphologie. 2, 111-128.

Enzel,Y., Bookman, R., Sharon, D., Gvirtzman, H., Dayan, U., Ziv, B., Stein, M., 2003. Late Holocene climates of the Near-East deduced from Dead Sea-level variations and modern regional winter rainfall. Quaternary Research. 60, 263-273. 
Farr, T., Rosen, P., Caro, E., Crippen, R., Duren, R., Hensley, S., Kobrick, M., Paller, M., Rodriguez, E., Roth, L., Seal, D., Shaffer, S., Shimada, J., Umland, J., Werner, M., Oskin, M., Burbank, D., Alsdorf, D., 2007. The Shuttle Radar Topography Mission. Rev. Geo-phys. 45 (http://www2.jpl.nasa.gov/srtm/srtmBibliography.html)

Fouache, E., Dufaure, J.-J., Denèfle, M., Lézine, A.-M., Léra, P., Prendi, F., Touchais, G., 2001. Man and environment around lake Maliq (southern Albania) during the Late Holocene. Vegetation History and Archaeobotany. 10, 79-86.

Frumkin, A., 1997. The Holocene History of Dead Sea Levels in: Niemi, T. M., BenAvraham, Z., Gat, J. R. (Eds.), The Dead Sea: The lake and its setting. Oxford University, pp. 237-248.

Huntley, B., Prentice, I.C., 1988. July temperature in Europe from pollen data, 6000 years before Present. Science. 241, 687-690.

Korkuti, M., 1995. Neolithikum und Chalkolithicum in Albanien, Philipp von Zabern, Mainz am Rhein

Lafe, O., 2005. Archaeology in Albania 2000-2004. Archaeological Reports. 51, 131133.

KOBAS, 2005. Korça Basin Archaeological Survey Project, Preliminary Report for the season 2005, Albanian Rescue Archaeological Unit (ARAU), (http://www.gshash.org)

Lera, P., 1990. Sovjan 1988. Iliria. 20, 250-252.

Lera, P., Prendi, F., Touchais, G., 1996. Travaux menés en collaboration avec l'École française d'Athènes en 1995. Sovjan (Albanie). Bulletin de Correspondance Hellénique. 120, 995-1026. 
Magny, M., 2006. Holocene fluctuations of lake levels in west-central Europe: methods of reconstruction, regional pattern, palaeoclimatic significance and forcing factors. Encyclopedia of Quaternary Geology, vol. 2, ed. Elsevier.

Magny, M., de Beaulieu, J.-L., Drescher-Schneider, R., Vannière, B., Walter-Simonnet, A.V., Miras, Y., Millet, L., Bossuet, G., Peyron, O., Brugiapaglia, E., Leroux, A., 2007. Holocene climate changes in the central Mediterranean as recorded by lake level fluctuations at Lake Accesa (Tuscany, Italy). Quaternary Science Reviews. 26, 1736-1758.

Magny, M., Vanniere, B., Zanchetta, G., Fouache, E., Touchais, G., Petrika, L., Coussot, C., Walter-Simonnet, A.-V., Arnaud, F., 2009. Possible complexity of the climatic event around 4300-3800 cal. BP in the central and western Mediterranean. The Holocene. 19, 6. 823-833.

Marchant, R., Hooghiemstra, H., 2004. Rapid environmental change in African and South American tropics around 4000 years before present: a review. Earth Science Reviews. 66, 217-260.

Masson, V., Cheddadi, R., Braconnot, P., Joussaume, S., Texier, L., 1999. MidHolocene climate in Europe: what can we infer from PMIP model-data comparisons? Climate Dynamics. 15, 163-182.

Prendi, F., 1966. La civilisation préhistorique de Maliq. Studia Albanica. 3,1, 255-280.

Prendi, F., 1990. Le Néolithique ancien en Albanie. Germania. 68, 410-418.

Reimer, P.J., Baillie, M.G.L., Bard, E., Bayliss, A., Beck, J.W., Bertrand, C., Blackwell, P.G., Buck, C.E, Burr, G., Cutler, K.B., Damon, P.E., Edwards, R.L., Fairbanks, R.G., Friedrich, M., Guilderson, T.P., Hughen, K.A., Kromer, B., McCormac, F.G., Manning, S., Bronk Ramsey, C., Reimer, R.W., Remmele, S., Southon, J.R., Stuiver, 
M., Talamo, S., Taylor, F.W., van der Plicht, J., Weyhenmeyer, C.E., 2004.

Radiocarbon. 46, 1029-1058.

Roberts, N., Reed, J.M., Leng, M.J., Kuzucuoglu, C., Fontugne, M., Bertraux, J., Woldring, H., Bottema, S., Black, S., Hunt, E., Karabiyikoglu, M., 2001. The tempo of Holocene climatic change in the eastern Mediterranean region: new highresolution crater-lake sediment data from central Turkey. Holocene. 11, 721-736.

Roberts, N., Jones, M.D., Benkaddour, A., Eastwood, W.J., Filippi, M.L., Frogley, M.R., Lamb, H.F., Leng, M.J., Reed, J.M., Stein, M., Stevens, L., Valero-Garcés, B., Zanchetta, G., 2008. Stable isotope records of Late Quaternary climate and hydrology from Mediterranean lakes: the ISOMED synthesis. Quaternary Science Reviews. 27, 25-26, 2426-2441.

Rodriguez, E., Morris, C.S., Belz, J.E., Chapin, E.C., Martin, J.M., Daffer, W., Hensley S., 2005. An assessment of the SRTM topographic products, Technical Report JPL D-31639. Jet Propulsion Laboratory, Pasadena, California. (http://www2.jpl.nasa.gov/srtm/srtmBibliography.html)

Sadori, L., Narcisi, B., 2001. The postglacial record of environmental history from Lago di Pergusa, Sicily. The Holocene. 11, 655-672.

Stevens, L.R., Ito, E., Schwalb, A., Wright Jr., H.E., 2006. Timing of atmospheric precipitation in the Zagros Mountains inferred from a multi-proxy record from Lake Mirabad, Iran. Quaternary Research. 66, 494-500.

Tagari, D., Vergely, P., Aliaj, S., 1993. Tectonique polyphasée plio-quaternaire en Albanie orientale (région de Korça-Pogradeçi). Bulletin de la Société Géologique de France. 164, 5, 727-737. 
Touchais, G., Fouache, E., 2007. La dynamique des occupations de bord de lac dans le Sud-Ouest des Balkans : l'exemple de Sovjan, bassin de Korça (Albanie) in: Richard, H., Magny, M., Mordant, C. (Eds.), Environnements et cultures à l’Âge du Bronze en Europe occidentale. Actes des congrès nationaux des sociétés historiques et scientifiques. Paris, pp. 375-386.

Touchais, G., Lera, P., Oberweiler, C., 2005. L'habitat préhistorique lacustre de Sovjan (Albanie) : dix ans de recherches franco-albanaises (1993-2003) in: Della Casa, P., Trachsel, M. (Eds.), WES '04. Wetlands Economies and Societies, Proceedings of the International Conference, Zurich, 10-13 march 2004. Zurich, pp. 255-258.

van Geel, B., Buurman, J., Waterbolk, H.T., 1996. Archaeological and palaeoecological indications of an abrupt climate change in The Netherlands, and evidence for climatological teleconnections around 2650 BP. Journal of Quaternary Science. 11, 451-460. 